\title{
Preliminary fish survey of Lac Tseny in north- western Madagascar
}

\author{
Daudet Andriafidison', Richard K. B. Jenkins', \\ Paul V. Loiselle", Tim McCaskie"', Andrinajoro A. \\ Rakotoarivelo', Justin Rahalambomanana ${ }^{\mathrm{IV}}$, Tsilavina \\ Ravelomanana", Noromalala Raminosoa ${ }^{\mathrm{IV}}$ and \\ Aleksei Saunders ${ }^{\vee}$
}

\author{
Correspondence: \\ Richard K. B. Jenkins \\ School of Environment, Natural Resources and Geography, \\ Bangor University, Gwynedd, LL57 2UW, U.K. \\ E-mail: jenkins@moov.mg
}

\begin{abstract}
We surveyed the fish fauna of Lac Tseny, in the Sofia Region of northwestern Madagascar, during October 2010 by observing commercial catches and targeted netting of areas used by endemic species. We recorded seven native fish species at the lake, including three endemic cichlids, a herring and a catfish. We confirmed the continued survival of the critically Endangered Paretroplus menarambo, as well as the presence of a Paretroplus taxon that may be new to science. The commercial fishery in the lake is sustained by introduced tilapiines and the native Sauvagella robusta. The three endemic cichlids (Paretroplus spp.) were not targeted by commercial fishermen, but when caught in small numbers were retained for domestic consumption. Submerged trees in the west of the lake restrict fishing with nets and probably provide important habitat for $P$. menarambo. Priority next steps at the lake include (i) additional surveys and biological studies of the endemic fish species and the Critically Endangered Madagascar big-headed turtle, Erymnochelys madagascariensis, (ii) clarification of the taxonomic status of Paretroplus cf. Kieneri and, should it prove a new taxon, its formal scientific description, and (iii) continued engagement with fishing communities and authorities to promote practices that benefit livelihoods and the survival of threatened fish species.
\end{abstract}

\section{RÉSUMÉ}

La composition spécifique de l'ichtyofaune du lac Tseny, dans l'ouest de Madagascar (région de Sofia) a été inventoriée au cours du mois d'octobre 2010, en observant les prises des pêcheurs et des pêches ciblées sur les espèces endémiques. Sept espèces de poissons indigènes ont été observées, dont trois cichlidés endémiques (Paretroplus menarambo, Paretroplus lamenabe et Paretroplus cf. Kieneri), un hareng indigène (Sauvagella robusta) et un poisson-chat (Arius madagascariensis). Deux de ces espèces sont classées comme Menacées dans la Liste Rouge de I'UICN : P. menarambo est une espèce en Danger Critique d'Extinction qui n'est con- nue que du lac Tseny et $A$. madagascariensis est une espèce en Danger d'Extinction et endémique de la région de Sofia. Un des poissons que nous avons inventorié dans le genre Paretroplus semble être une forme non décrite. Les pêcheurs ont indiqué que $P$. menarambo est associé à des arbres immergés le long de la rive occidentale du lac qui offrent un habitat propice à la reproduction et à I'alimentation. Ces arbres immergés empêchent I'utilisation des filets pour la pêche et limitent ainsi la pression de pêche qui s'exerce sur cette espèce. Les trois espèces endémiques de Paretroplus sont prisées par les pêcheurs qui les gardent pour leur consommation personnelle plutôt que de les vendre. La pêche commerciale pratiquée dans le lac semble pérenne grâce à la présence de tilapias allogènes et du hareng indigène (Sauvagella robusta) qui approvisionnent les marchés de poisson local (Tsaratanana), régionaux (Boriziny et Mandritsara) et national (Antananarivo). Les populations locales ont rapporté que la surpêche, l'immigration, I'utilisation illégale de filets à petit maillage et le non respect de la saison de fermeture de la pêche étaient les principales menaces pesant sur l'ichtyofaune du lac Tseny. Une baisse de la pêche commerciale pourrait entraîner une ruée vers les espèces endémiques et l'ouverture des zones d'arbres immergés pour la pêche. Le lac Tseny abrite un assemblage unique de poissons qui doivent être protégés dans leur habitat qui est essentiel aux cichlidés endémiques par le maintien d'une pêche commerciale pérenne. Les prochaines étapes à mener en priorité pour le lac incluent: (i) des études supplémentaires sur la biologie des poissons endémiques et de la Podocnémide de Madagascar (Erymnochelys madagascariensis), une tortue en Danger Critique d'Extinction, (ii) la clarification du statut taxinomique de Paretroplus cf. kieneri qui pourrait être une nouvelle espèce et sa description, le cas échéant, et (iii) I'engagement continu avec les communautés de pêcheurs et les autorités locales pour promouvoir des pratiques équitables en faveur des populations riveraines et pour la survie des espèces de poissons menacées.

\footnotetext{
Madagasikara Voakajy, B. P. 5181, Antananarivo 101, Madagascar, Phone: +261 202252379.

New York Aquarium, Surf Avenue \& West 8th Street, Brooklyn, New York 11224, U.S.

Toronto Zoo, 361A Old Finch Avenue, Toronto, Ontario, M1B 5K7, Canada.

Department of Animal Biology, University of Antananarivo, B.P. 906, Antananarivo 101, Madagascar.

Denver Zoo, 2300 Steele Street, Denver, CO 80205-4899, U.S.
} 


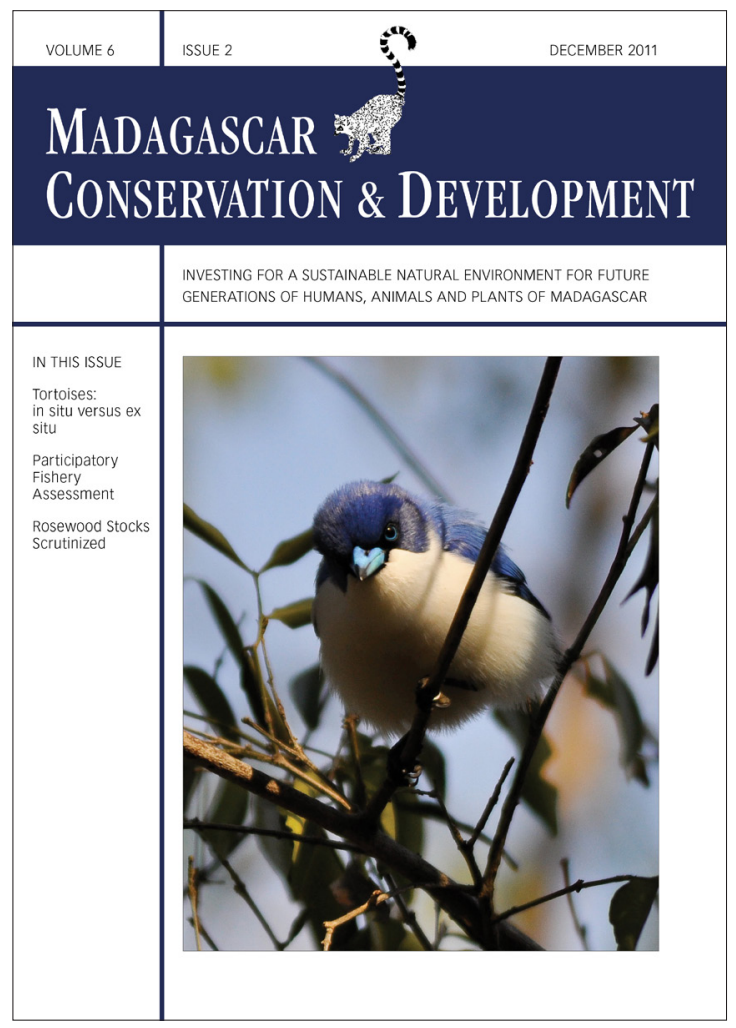

Madagascar Conservation \& Development is the journal of Indian Ocean e-Ink. It is produced under the responsibility of this institution. The views expressed in contributions to MCD are solely those of the authors and not those of the journal editors or the publisher.

All the Issues and articles are freely available at http://www.journalmcd.com

Contact Journal MCD

info@journalmcd.net for general inquiries regarding MCD funding@journalmcd.net to support the journal

Madagascar Conservation \& Development Institute and Museum of Anthropology University of Zurich

Winterthurerstrasse 190

CH-8057 Zurich, Switzerland

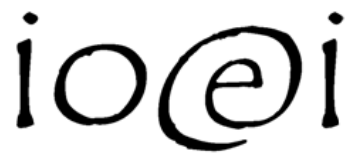

Indian Ocean e-Ink

Promoting African Publishing and Education www.ioeink.com

Missouri Botanical Garden (MBG)

Missouri Botanical Garden

Madagascar Research and Conservation Program BP 3391

Antananarivo, 101, Madagascar 


\section{INTRODUCTION}

Freshwater fishes and their habitats are severely threatened in Madagascar (Benstead et al. 2003) because of over-fishing, exotic species and deforestation (Reinthal and Stiassny 1991, Sparks and Stiassny 2003, Irwin et al. 2010). Many endemic fish species are now restricted to a tiny proportion of their original range and are on the verge of extinction (Reinthal and Stiassny 1991, Benstead et al. 2003, Sparks and Stiassny 2008, Irwin et al. 2010). The pinstripe damba, Paretroplus menarambo, was described in 1996 from Sarodrano in western Madagascar (Allgayer 1996). This population of P. menarambo subsequently became threatened by over-fishing and habitat degradation (Benstead et al. 2003, Sparks and Stiassny 2003) and was considered to be extinct in the wild by 2003 (Loiselle and de Rham 2003). It is currently listed as Critically Endangered (CR) on the IUCN Red List of Threatened Species (Loiselle 2008), and is only reported to occur in Lac Tseny, although populations are maintained in captivity in five institutions (ISIS 2011). In October 2010 we conducted a rapid ichthyological assessment of Lac Tseny to provide additional information on the conservation status of $P$. menarambo.

\section{METHODS}

STUDY SITE. DA visited Lac Tseny in July 2010 for a preliminary meeting with fishermen to inquire about P. menarambo. A five-person survey team (DA, AS, TM, JR, AAR) then visited Lac Tseny between 14 and 16 October 2010. The lake is located within the Port Bergé District of the Sofia Region and is $26 \mathrm{~km}$ straight-line distance from Lac Sarodrano (Figure 1). Lac Tseny is located within a wetland complex in the lower catchment of the Sofia River. It undergoes major fluctuations in water level in accordance with the rainy (January-April) and dry seasons (May-December) in western Madagascar. The villages of Anjia, Ambario, Ankazobe, Anjiajia and Antanankova are located on the lakeshore and the nearest town is Tsaratanana, which had an estimated population of 8,720 in 2001 (INSTAT 2001). No human census data are available for populations in these smaller villages.

SURVEY. The team conducted interviews with local

authorities and five fishermen in the village of Ambario (E47 $59,591^{\prime}, \mathrm{S} 15^{\circ} 39,752^{\prime} ; 45 \mathrm{~m}$ a.s.I.) to obtain a descrip-

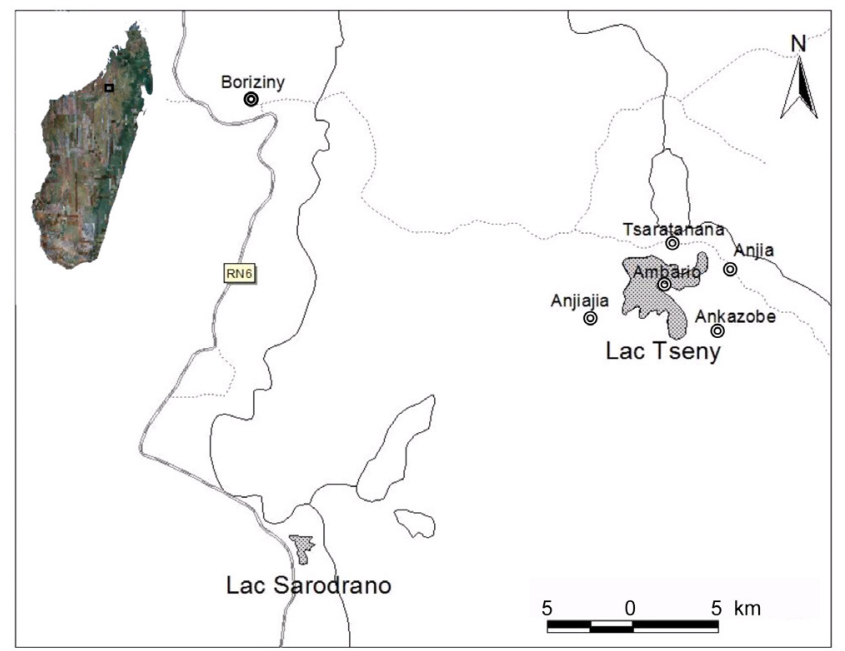

FIGURE 1. Map showing Lac Sarodrano and Lac Tseny in northwestern Madagascar. Route National 6, and Boriziny are also shown. tion of the fishery and discern the main issues concerning the management of the lake. We also surveyed the composition of the catch by talking with fishermen and inspecting their catches as they landed their pirogues. In addition, because fishermen would not normally set nets to capture native cichlids, we occasionally employed them to fish in areas that they identified as of potential importance for P. menarambo. The communities around the lake consist of part-time fishermen who also tend their farmland nearby, and professional fishermen who are predominantly recent immigrants. Approximately one third of all fishermen from the four villages we visited are members of a cooperative funded by IFAD (International Fund for Agricultural Development) to promote sustainable fishing and improved marketing.

REFERENCE COLLECTION. We photographed each species encountered. Voucher specimens of the endemic species were taken and deposited in the Department of Animal Biology, University of Antananarivo (within the reference collection they only have been stored, not accessioned). Voucher specimens were identified by using morphological characteristics and available reference materials at the University of Antananarivo and at the American Museum of Natural History (AMNH). Tissue samples of the Paretroplus spp. were also collected and sent to the AMNH for DNA analysis.

\section{RESULTS}

We found seven native species in Lac Tseny: Three endemic Cichlidae (Paretroplus menarambo (Figure 2a), Paretroplus lamenabe (Figure 2b), Paretroplus cf. kieneri (Figure 2c)) and Arius festinus (Ariidae, Figure 2d), Megalops cyprinoides (Megalopidae), Sauvagella robusta (Clupeidae, Figure 2e) and Glossogobius giuris (Gobiidae, Figure 2f). We also confirmed the presence of the following non-native species in the lake: Heterotis niloticus (Cuvier 1829) (Arapaimidae), Channa maculata (Bloch 1793) (Channidae), Cyprinus carpio (Linnaeus 1758) (Cyprinidae) and three tilapiine species (Cichlidae) Oreochromis n. niloticus (Linnaeus 1758), O. mossambicus (Peters 1852) and Tilapia zillii (Gervais 1848).

\section{Paretroplus menarambo (Allgayer 1996)}

Menarambo (vernacular name)

IUCN Red List: Critically Endangered (Loiselle 2008)

An endemic species with an extant distribution restricted to Lac Tseny (Loiselle 2008). This species was caught by local fishermen using seine nets, known locally as koka, set in a wide arc and pulled to shore by a team of two to four people. It was present in many of the catches we inspected but always in small numbers, generally two to four individuals. In total, we observed sixteen individuals and three voucher specimens were taken. Fishermen reported $P$. menarambo are frequently found in or around submerged wood but could also sometimes be netted in other areas. The best fishing areas for this species are reportedly in the vicinity of the sunken trees along the southwestern shore. Fishermen reported that the species breeds during October and November and that it is caught in the highest numbers between October and December. 

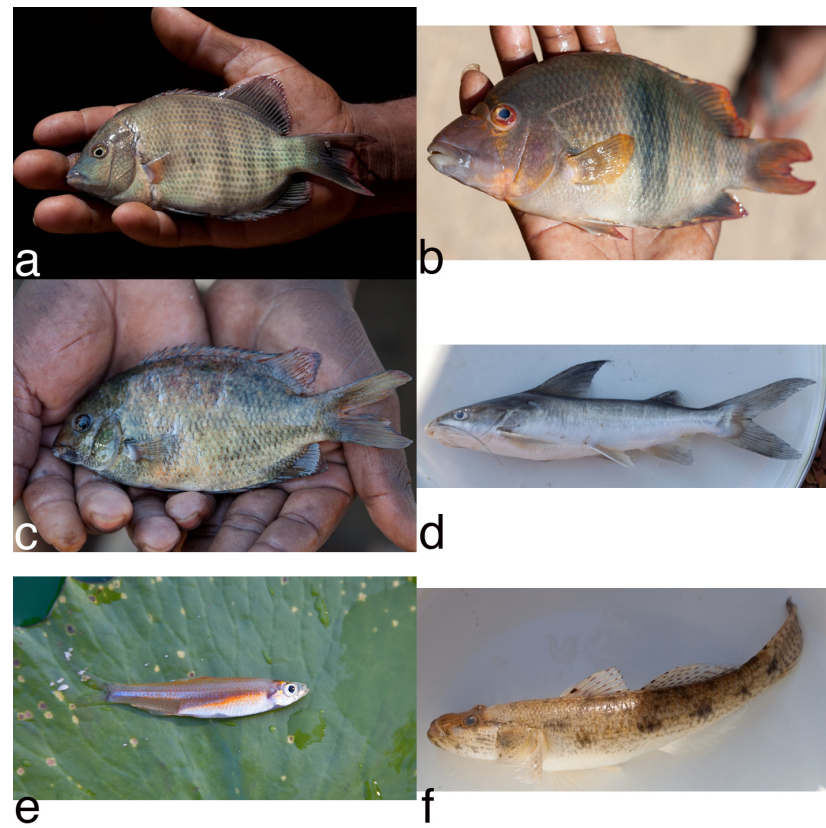

FIGURE 2. (a) Paretroplus menarambo, (b) Paretroplus lamenabe, (c) Paretroplus cf. kieneri, (d) Arius festinus, (e) Sauvagella robusta, (f) Glossogobius giuris. All photos taken at Lac Tseny by A. Saunders.

Paretroplus lamenabe (Sparks 2008)

Lamena (vernacular name)

IUCN Red List: Not Evaluated

This is an endemic species that was previously known only from the lower reaches of the Mahajamba River in northwestern Madagascar (Sparks 2008). This species was also caught by local fishermen using koka. It was present in many of the catches we observed, but always in small numbers (one to two individuals). In total, we observed nine individuals and two voucher specimens were taken. This species was caught less frequently than $P$. menarambo, although fishermen report that $P$. lamenabe is actually more abundant in Lac Tseny than P. menarambo. Fishers reported catching this species in the south and west of Lac Tseny and that it breeds during the months of October and November.

\section{Paretroplus cf. kieneri}

Kotsovato (vernacular name)

IUCN Red List: Not Evaluated

This taxon shared affinities with P. kieneri, such as the absence of any traces of vertical banding, and the presence of blotchy orange, grey, and brown pigmentation, but may warrant species status because of its small size and unusual rostral profile (de Rham and Nourissat 2003). This species was caught using koka set in a wide arc and pulled to shore by teams of two to four people. This taxon appeared as frequently as $P$. menarambo in the catches that we inspected.

Arius festinus (Ng and Sparks 2003)

Gogo (vernacular name)

IUCN Red List: Endangered (Loiselle et al. 2004a)

This endemic catfish species is only known from the Sofia Region, where it has been collected from the Amboaboa River, a tributary of the Mangarahara River, itself a left bank tributary of the much larger Sofia River ( $\mathrm{Ng}$ and Sparks 2003). This species was caught using the doboka method, which consists of setting a gill net either at the mouth of a small bay or around submerged trees and smacking the water surface to scare fish out of cover and into the net. Our team was never present during the capture of $A$. festinus and specimens were always brought to us as single individuals. In total, we observed three individuals and two voucher specimens were taken.

Sauvagella robusta (Stiassny 2002)

Varilava (vernacular name)

IUCN Red List: Data Deficient (Loiselle et al. 2004b)

This native species is a freshwater herring only known from the Mangarahara tributary of the Sofia River in northwestern Madagascar (Stiassny 2002). The Lac Tseny population therefore represents a range extension. This was the predominant fish species observed in commercial catches from the east of the lake.

Megalops cyprinoides (Broussonet 1782)

Besisika (vernacular name)

IUCN Red List: Not Evaluated

This native species is widespread in coastal northern Madagascar (Sparks and Stiassny 2003) and elsewhere in the Indo-Pacific region. This species was also caught using the doboka method as well as by setting gill nets in deep water at night. We observed two individuals, but fishermen reported that this species was frequently netted.

Glossogobius giuris (Hamilton1822)

Amborodoa (vernacular name)

IUCN Red List: Not Evaluated

This native species is widespread in Madagascar and occurs in other parts of Africa and Asia (Sparks and Stiassny 2003). This species is caught using both gill and seine nets throughout the year. It was present in all of the catches we observed, in small numbers from gill nets (two to three individuals) and in the thousands from seine nets.

All fishermen reported that the endemic cichlids were harvested accidentally as by-catch and were not of commercial importance. The fishermen seemed to appreciate the taste of these species, however, and kept these fish for their own domestic consumption. Commercial catches, based on fishermens' reports and our observations, consisted of mainly tilapiines, Sauvagella robusta and Glossogobius giurus, which supply local markets as well as Boriziny, Mandritsara and the capital city of Antananarivo.

A number of bays that we visited on the western shore of the lake contained permanently submerged trees, which provide habitat for the aquatic fauna of Lac Tseny. In some cases only the uppermost branches emerge from the water, whereas the tree trunks and associated debris are submerged. In other areas the entire tree is underwater. The submerged trees hindered fishing access to certain areas and fishermen refrained from setting nets in these areas because of the risk of damage from 
underwater snags. These areas are therefore subject to minimal fishing pressure, although fishermen sometimes set nets in the open water adjacent to the sunken forest and attempt to scare the fishes into the nets. The fishermen reported that the sunken forests are used by endemic fishes as breeding sites and also by the endemic Madagascar big-headed turtle (Erymnochelys madagascariensis). Interviewees cited over-fishing, immigration, illegal (small) mesh sizes and fishing during the closed season as the main threats to the Lac Tseny fishery.

Thirty-seven people participated in a two-day meeting held in Boriziny on 3 and 4 February 2011 to discuss the results of the ichthyological survey at Lac Tseny. A day was devoted to discussing fish and a half-day to freshwater turtles. The participants included the Regional Director and Representative of the Ministry of Environment and Forests, Regional Director and Representative of the Ministry of Fisheries and Aquatic Resources and representatives from Conservation International and communities around the lake (e.g., Ambanjabe, Tsarahasia and Tsaratanana). The objective of the workshop was to inform stakeholders about the results of the fish survey and discuss future options for managing the lake.

Priority research activities over the next two years at Lac Tseny include (i) biological studies on Paretroplus menarambo and Sauvagella robusta, (ii) assessment of major seasonal variation in the lake's habitats and fish stocks and (iii) evaluation of the taxonomic status of $P$. cf. kieneri. Activities orientated towards conservation include (iv) occasional bans on the use of seine nets, (v) awareness raising campaign about fishery laws, (vi) limiting the expansion of new human settlements near the lake and (vii) mapping to identify key conservation, fishery and cultural features. There was also consensus to (viii) provide more training and equipment to fishermen to encourage adoption of improved techniques and (ix) more support for fishermen's cooperatives. An assessment of the other lakes within the Port Bergé wetlands is also needed to identify any other nationally important sites. Future surveys at Lac Tseny, and elsewhere in the region, should also focus on assessing the conservation status of the Critically Endangered Madagascar big-headed turtle (Erymnochelys madagascariensis).

\section{DISCUSSION}

Lac Tseny is a wetland of considerable importance for both people and biodiversity. It has a unique assemblage of endemic and threatened fish species and sustains an important commercial fishery. The submerged trees along the western shore appear to be a key feature of the lake, and the presence of this refugium probably supports substantial recruitment of endemic cichlids. Tangled roots and branches provide predator -free and competitor-free space for these species, and dendrophilous algae and bacteria may support large populations of invertebrate prey for juvenile and adult Paretroplus (Kiener 1963, Catala 1979). Paretroplus species are substratum spawners and require a firm surface upon which to lay their eggs (de Rham and Nourissat 2003). The sunken wood along the western shore of Lac Tseny therefore appears to represent essential habitat for fish concealment, foraging and breeding.

Fishing pressure on the main commercial species probably has little impact on the endemic cichlids. The main Sauvagella robusta fishery is located along the eastern shore and is spatially isolated from the submerged trees on the western shore. The gill nets used to target the tilapiines in deep open water throughout the lake are unsuitable for catching the largely bottom-feeding endemic cichlids. A potential concern for the future, therefore, is that major declines in the commercial fishery for either $S$. robusta or tilapiines might lead to fishermen targeting endemic cichlids and clearing areas within the submerged wood fishing with nets. It is therefore important from a conservation perspective to maintain the Lac Tseny commercial fishery as well as the endemic fish populations.

Although some freshwater habitats are included within Madagascar's network of strict protected areas, only Lac Tsimanampetsotsa in southern Madagascar is protected primarily for its aquatic ecosystem (ANGAP 2003). In the last twenty years, greater conservation attention has been given in Madagascar to freshwater lakes, primarily because of their importance to birds, and seven are now listed as Ramsar sites and subject to conservation management (Ramsar 2011). There have been few direct attempts to conserve rivers, with the only reported conservation efforts occurring in eastern Madagascar (for the Nosivolo River, which was granted Ramsar status in 2007 mainly because of its importance to endemic fishes (Ramsar 2011)). Lac Tseny is included in the Port Bergé Wetlands, an area of $80,279 \mathrm{~km}^{2}$, which was identified as a national biodiversity conservation priority during a review conducted in 2005 (MEF 2011). However unlike other sites, it never received further consideration as a new protected area. It is evident from this survey that Lac Tseny is of national importance because it supports apparently viable populations of endemic fish as well as a commercial fishery, and is one of the few remaining examples of its kind in Madagascar.

Priority action in the short term at Lac Tseny should focus on obtaining more information about the state of the commercial fishery and endemic fish populations. Although Stiassny (2002) stated that there is no commercial or artisanal Sauvegella fishery in Madagascar, $S$. robusta is a major component of the fishery in Lac Tseny. Additional surveys of the endemic cichlids should focus on confirming the role of the submerged trees as key habitats for conservation. Conservation organizations, government and local stakeholders should continue to collaborate because Lac Tseny needs to function as a commercial fishery whilst maintaining populations of its unique assemblage of endemic fishes.

\section{ACKNOWLEDGEMENTS}

For granting us permission to do the survey we thank the Ministère de I'Environnement et des Forêts and the Ministère de la Pêche et des Ressources Halieutiques. For supporting our work in the Sofia Region we would like to thank the Chef de Région Sofia, the Directeur Régional de Développement Rural Sofia, the Direction Régionale de I'Environnement et des Forêts Sofia, the Direction Générale de la Pêche et des Ressources Halieutiques and the Chef de District de Port-Bergé. We thank Dr. Hanta Razafindraibe from the Département de Biologie Animale, Université d'Antananarivo and Benjamin Andriamihaja from MICET for assisting this project. We are also grateful to the people in Tsaratanana and Ambario for their assistance and patience. Julie Razafiamanahaka and Robel Randrianarison assisted the July 2010 mission. We would like to thank Conservation International for funding our reconnaissance mission in July 2010. The October 2010 survey was 
funded by the North of England Zoological Society at Chester Zoo, Denver Zoo, Toronto Zoo and Madagasikara Voakajy and the February stakeholder meeting was funded by Denver Zoo and the Darwin Initiative. We thank two anonymous reviewers and Julie Razafiamanahaka for helping us to improve our original submission.

\section{REFERENCES}

Allgayer, R. 1996. Description d'une espèce nouvelle du genre Paretroplus Bleeker (Teleostei: Cichlidae) de Madagascar. Revue Française des Cichlidophiles 159: 6-20.

ANGAP 2003. Madagascar Protected Area System Management Plan. ANGAP, Ministry of the Environment, Water and Forests. Antananarivo, Madagascar.

Benstead, J. P., de Rham, P. H., Gattolliat, J.-L., Gibon, F.-M., Loiselle, P. V., Sartori, M., Sparks, J. S. and Stiassny, M. L. J. 2003. Conserving Madagascar's freshwater biodiversity. Bioscience 53, 11: 1101-1111. (doi:10.1641/0006-3568(2003)053[1101:CMFB]2.0.CO;2)

Catala, R. 1979. Poissons d'eau douce de Madagascar (suite). Revue Française d'Aquariologie 6: 125-128.

de Rham, P. H. \& Nourissat, J.-C. 2003. Les Cichlidés Endémiques de Madagascar. Publication Association France Cichlid, Solliès-Pont, France.

INSTAT 2001. <http://www.ilo.cornell.edu/ilo/data.html> accessed 27 October 2011.

Irwin, M. T, Wright, P. C., Birkinshaw C., Fisher, B. L., Gardner, C. J., Glos, J., Goodman, S. M., Loiselle, P., Rabeson, P., Raharison, J.-L., Raherilalao M. J., Rakotondravony, D., Raselimanana, A., Ratsimbazafy, J., Sparks, J. S., Wilmé, L. and Ganzhorn, J. U. 2010. Patterns of species change in anthropogenically disturbed forests of Madagascar. Biological Conservation 143, 10: 2351-2362. (doi:10.1016/j.biocon.2010.01.023)

Kiener, A. 1963. Poissons, Pêche et Pisciculture à Madagascar. Publication Centre Technique Forestier Tropical 24: 1-244.

ISIS (International Species Information System). 2011. <WWW.isis.org> accessed 25 October 2011.

Loiselle, P. V., and participants of the CBSG/ANGAP CAMP «Faune de Madagascar» workshop 2004a. Arius festinus. In: IUCN 2011. IUCN Red List of Threatened Species. Version 2010.4. Available at <http://www. iucnredlist.org/apps/redlist/details/44461/0>
Loiselle, P. V., and participants of the CBSG/ANGAP CAMP «Faune de Madagascar» workshop 2004b. Sauvagella robusta In: IUCN 2011. IUCN Red List of Threatened Species. Version 2010.4. Available at <http:// www.iucnredlist.org/apps/redlist/details/44661/0>

Loiselle, P. V. 2008. Paretroplus menarambo. In: IUCN 2010. IUCN Red List of Threatened Species. Version 2010.4. Available at <http://www. iucnredlist.org/apps/redlist/details/44461/0>

Loiselle, P. V. and de Rham, P. 2003. Paretrop/us, Damba. In: The Natural History of Madagascar. S. M. Goodman and J. P. Benstead (eds.), pp 877-878. The University of Chicago Press, Chicago.

MEF (Ministère de l'Environnement et des Forêts). 2011. <http://Www. meeft.gov.mg/index.php?option=com_sapm\&task=RESULTPOTENTIEL> accessed 10 November 2011.

Ng, H. H. and Sparks, J. S. 2003. The ariid catfishes (Teleostei: Siluriformes: Ariidae) of Madagascar, with the description of two new species. Occasional Papers of the Museum of Zoology, University of Michigan 735: 1-21.

Ramsar 2011. <http://www.ramsar.org/cda/en/ramsar-pubs-annolist-annomadagascar/main/ramsar/1-30-168\%5E16534_4000_0> accessed 1 November 2011.

Reinthal, P. N. and Stiassny, M. L. J. 1991. The freshwater fishes of Madagascar: A study of an endangered fauna with recommendations for a conservation strategy. Conservation Biology 5, 2: 231-243. (doi:10.1111/j.1523-1739.1991.tb00128.x)

Sparks, J. S. 2008. Phylogeny of the cichlid subfamily Etroplinae and taxonomic revision of the Malagasy cichlid genus Paretroplus (Teleostei: Cichlidae). Bulletin of the American Museum of Natural History 314: 1-151. (doi:10.1206/314.1)

Sparks, J. S. and Stiassny, M. L. J. 2003. Introduction to freshwater fishes. In: The Natural History of Madagascar. S. M. Goodman and J. P. Benstead (eds.), pp 849-863. The University of Chicago Press, Chicago.

Sparks, J. S. \& Stiassny, M. L. J. 2008. Les poissons d'eau douce. In: Paysages Naturels et Biodiversité de Madagascar. S. M. Goodman (ed.), pp 283-309. Publications Scientifiques Muséum national dıHistoire naturelle (MNHN), Paris.

Stiassny, M. L. J. 2002. Revision of Sauvagella Bertin (Clupeidae; Pellonulinae; Ehiravini) with a description of a new species from the freshwaters of Madagascar and diagnosis of the Ehiravini. Copeia 2002, 1: 67-76. (doi:10.1643/0045-8511(2002)002[0067:ROSBCP]2.0.CO;2) 